\title{
The Extent of Possession of Knowledge Management Requirements Among the Principals of Public Secondary Schools in Mafraq Governorate
}

\author{
Tarad A. Al Khuzam ${ }^{1}$ \\ Correspondence: Tarad A. Al Khuzam. E-mail: drzboon@yahoo.com
}

Received: Oct. 27, 2018

doi:10.5539/mas.v13n1p226

Accepted: Nov. 8, 2018

Online Published: December 31, 2018

URL: https://doi.org/10.5539/mas.v13n1p226

\begin{abstract}
The aim of this study is to identify the extent of possession of knowledge management requirements among the principals of public secondary schools in Mafraq Governorate. In order to achieve the objectives of the study, the study population will consist of all school principals in Mafraq Governorate in the Hashemite Kingdom of Jordan for the academic year 2018, namely: (120) male and female principals at undergraduate levels and (150) male and female principals at postgraduate levels, i.e. (145) male principals, and (125) female principals, leading them to represent the study sample. To achieve the objectives of the study and answer its questions, the researcher formatted a 20 -item questionnaire.

The researcher conducted an explanation of the results using the descriptive approach, where he used the arithmetic means, the standard deviations and the $\mathrm{T}$ tests to determine the significance of the differences according to the variables of the study. The results showed that the extent of possession of knowledge management requirements among the principals of public secondary schools in Mafraq Governorate was in a high degree. The results also showed that there were statistically significant differences at the level of 0.05 or less due to the difference of academic qualification for the postgraduate qualification. The results also showed no statistically significant differences at the level of 0.05 or less due to the difference of gender.

In the light of the previous results, the researcher recommended working to increase the training workshops for school principals and employees to make the process of knowledge management succeed and get use of it in the field of education, benefit from the information and communication revolution in the field of education, implement the knowledge management strategy as received from the Ministry of Education and train all concerned on its terms and contents, especially those with a bachelor's degree only, work to link schools to each other with electronic interacting networks for its significance and exchange of experiences, and raise the efficiency of staff in schools in general to be able to follow up everything that is new in the world of knowledge and technology.
\end{abstract}

Keywords: knowledge management, public high schools, school principal, extent of possession

\section{Introduction}

Knowledge management is one of the main approaches highlighted by modern literature, which directly affects the effectiveness of institutions and the efficiency of their members in dealing with their daily situations. Knowledge management is defined as the term associated with the process of creating and disseminating their future, testing and integrating knowledge within the institution, and how to benefit from them in a way that contributes to the development of their job performance.

Knowledge management has become one of the most prevalent approaches at present. As the information and communications revolution has developed, we have been thinking seriously about applying knowledge management to the use of information technology. The world is undergoing an unprecedented transformation in knowledge and information, which need to provide qualified human beings that can contribute in recruiting benefitting from them to serve communities. It is imperative for societies to support, develop and improve human cadres so that they are able to cope with these developments and use them as efficiently as possible (Al-Sabbagh (2002).

This has become apparent after governments have begun to give greater attention to organizations with a better level of knowledge in the sense that they have an outstanding level of excellence in how to acquire, handle, apply and benefit from knowledge. In light of this, the concept of knowledge management lies in the development of 
knowledge and acquiring skills in managing the knowledge of workers in the easy and appropriate time and form to achieve higher levels of achievement (Rozki, 2005).

Maani (2009) pointed out that knowledge management has introduced a concept of knowledge that has not emerged from the academic community, as is the case with traditional educational theories, but it has emerged from the core of professional work. The formation of knowledge here takes place in business corporations for the purpose of real work, gaining experience and exchanging ideas, not with the aim of obtaining information. The acquisition of competitive advantages by business corporations in the market depends mainly on the extent to which knowledge management succeeds in achieving its objectives.

One of the most important elements of the success of institutions is the ability to catch up with the latest developments in the era of the technological and information revolution as a result of the tremendous development that has taken place in communication technology and its uses in the field of information and knowledge. The tremendous increase in information and its accumulation have led to the urgent need to develop a modern concept that organizes, exploits and manages this information to make the most of it in achieving strategic objectives for institutions and supporting decision-makers in their decision-making (Khalili, 2006).

Now, the modern educational systems are paying attention towards the management of knowledge, which is one of the components of the success of educational systems to be able to cope with the changes witnessed by the era of technological and information revolution as a result of the evolution of communication technology and its uses in the field of information. It can be said that the school administration is part of the educational administration and a miniature picture of its organization, and the conscious school administration aims to improve the educational process and improve the level of performance by enlightening the staff of the school with their responsibilities and guide them based on systematic procedures (Kubaisi, 2005). Thus, the educational system emerges as the most important driver for immediate change and a real revolution in thinking, starting from family and school to research centers and universities so that the knowledge and means that support their collection, preservation, analysis and employment become the basis of the educational system (Al-Malkawi, 2007).

Al-Balawi and Hussein (2007) point out that education provides quality of life within educational institutions, whether for students or working individuals. From the perspective of community knowledge and information technology, this includes participation in building an education system based on strong knowledge bases, responsibilities for the development of school work and educational services provided to students. Although these issues are clear in the field of education, the real opportunities for addressing them have not been provided through good system methods. Hence, the importance of knowledge management lies in providing new opinions, ideas and effective practices to ensure the excellence and quality of the educational administration. Then, there is a new responsibility for the administration, which is the management of organizational knowledge in educational institutions. It can be said that schools in general and secondary schools in particular are among the most important organizations that produce and invest in knowledge, and are organizations that build knowledge management in the right way and structure.

Al-Rifa'i (2004) defines knowledge management as an attempt to identify and elevate the capabilities embedded in the minds of individuals to be a kind of organizational asset that can be accessed and utilized by a group of individuals whose decisions are fundamentally dependent on the organization. It is also the commitment of the organization to create new knowledge relevant to the functions of that organization and to disseminate them within it and reflect them in the form of specific goods, services and systems.

While Razzouki (2005) defines knowledge management as it is to maximize the efficiency of intellectual capital use in business, but requires networking and connection of the best minds in individuals through collective participation and collective thinking.

As for Malhorta (1994), she argues that knowledge management seeks to provide solutions to issues and problems of knowledge encouraging, production and participation among individuals, groups and organizations. In other words, it is interested in investing knowledge resources and building a memory for the organization based on knowledge sharing and participation through a systematic process.

Deemeng (2003) points out that knowledge management is an organized process of searching for, selecting, organizing, and classifying information in a way that increases staff understanding, along with storing them in a way that improves the general intelligence of the organization. This will provide flexibility in work, preserve intellectual assets from loss, and make use of them in solving work problems in education, increasing the capacity for strategic planning and decision-making, and learning through the experiences in which they went through.

Moussa (2006) mentioned a number of objectives of the application of knowledge management in educational 
institutions, namely: raising the efficiency of the educational system, increasing its efficiency, developing the infrastructure of its institutions, and restructuring the educational model and reviewing the educational policies, building a national strategy for education, producing a generation equipped with science, knowledge and technology capable of producing, using knowledge and applying it in the field, developing the institutional competence able to manage the educational system efficiently, achieve the goals effectively through adoption of modern administrative methods and coordinate among all concerned sectors to take the appropriate decision in a timely manner.

Al-Ali, Qandilji and Al-Omari (2009) suggest that knowledge management achieves its core functions through defining the knowledge resources of the organization, their nature, content, forms, access methods, uses and obstacles. The management of the knowledge strategy includes all activities organized to formulate the knowledge strategy, organize knowledge and make it available, build knowledge systems, develop the collective mind, build teams and encourage staff of all units to work as an integrated team to maximize the value of knowledge work as a whole.

Rastogi (2001) summarized the success factors of knowledge management by providing continuous learning opportunities for individuals, enhancing innovation, providing opportunities for individuals, engaging in dialogue, research and discussion, establishing systems for understanding, disseminating and sharing learning, encouraging development and collective vision, and helping individuals define its roles, requirements, knowledge content and applications to accomplish their work and identify leaders who build, develop and support learning models at the individual, team and institution levels.

A number of researchers (Alayan, 2012; Alani et al., 2012, and Maani, 2009; Hijazi, 2005) argue that the implementation of knowledge management programs faces a number of important problems and obstacles such as the weak commitment of senior management to the management and support of knowledge, and the weak understanding of the concept of knowledge management, content, requirements and the importance of its role in the organization, the weak organization of the knowledge management, the ambiguity between the explicit knowledge, the implicit knowledge, the overlap between them, the difficulty of separating, the weakness in giving an importance of databases and knowledge bases, the different level of knowledge among employees and the lack of desire to share knowledge for fear of loss of personal excellence among some employees, the separation of knowledge from its users and beneficiaries, its monopoly by traditional senior management, leading to difficulty in benefiting from it, the lack of time to plan and implement knowledge management, poor budgets allocated to knowledge management or even lack of availability at times, insufficient attention to the creation of knowledge or development and lack of necessary research and experiments, and relying on the acquisition of knowledge from the specialized bodies, which leads to the reduction of thinking, analyses and search for the employees of the organization.

Moreover, knowledge management in schools depends not only on the collection of data from individuals, nor on the involvement of individuals with some business enterprises, nor on their involvement with one another as in the business management world, but relies on strategic application, development and support of management information systems and on the views and attitudes of school principals in their management style. For example, the policies of public schools affect the way schools manage knowledge and how they perform their teaching functions. Halaq (2014) pointed to a number of procedures to be followed through transformation from information management to knowledge management, transformation from data to information and then to knowledge, assessment of currently available information, identification of the information required for decision-making, working in an environment that promotes school and educational progress and assessment of school cultures and policies towards the collection process of information and data.

In this context, Al-Khalili conducted a study to monitor and analyze the extent of knowledge management activities at the Ministry of Education in the Hashemite Kingdom of Jordan and to clarify the importance of knowledge management as an administrative concept that helps the Ministry of Education to improve its services and contribute to building the knowledge economy society. In order to achieve the objectives of the study, the researcher designed a questionnaire distributed on a random stratified sample. The study population consisted of (755) principals from all the principals of the Ministry of Education. The main findings of the study are: the consolidation of the concept of knowledge management through the exercise of the activities included in this concept. It also found that there is a positive statistical relationship between the nature of the strategy of knowledge management and the extent of the practice of knowledge dissemination activity. Besides, it found that there no statistical differences in the practice of knowledge management activities due to gender variable. One of the most important recommendations was the need to expand the study of the concept of knowledge management due to the importance of this concept in supporting the ability of the course on excellence and creativity. 
The study of Halaq (2014) was conducted to identify the role of knowledge management practiced by principals and teachers in the decision-making process in general secondary schools in Damascus City from the point of view of principals and teachers. The sample consisted of 76 secondary school principals in Damascus, where (500) teachers of the general secondary school teachers in Damascus were randomly selected. The researcher used the descriptive analytical method which is based on data collection, tabulation and analysis, and then attaining the results. The researcher prepared the study instrument, which is a questionnaire to study the reality of the practice of knowledge management at the public secondary schools in Damascus and the reality of the practice of decisionmaking in these schools. The questionnaire consisted of (83) items divided into two areas (knowledge management, decision making), and the most prominent results of the study is the absence of any significant statistical differences in the practice of knowledge management among school principals due to the variables (gender, experience, academic qualification). It recommended that an appropriate strategy for knowledge management should be drawn up by the Ministry of Education, along with establishing of a specialized department for knowledge management and information technology to support decisions to ensure maximum returns.

Chen and Wei (2007) studied knowledge management in order to facilitate online peer learning, so that it is based on the Internet as a platform for students to share their knowledge with peers. The researcher used the semiexperimental method. The number of the study members of the three groups was 77 students selected from three Chinese universities in Hong Kong. One of the findings of the study is that there is a role of knowledge management in increasing the effectiveness of performance and learning in a peer way.

Cranfield (2011) aimed at reviewing current perceptions of knowledge management in the context of higher education in the UK and factors that hinder their use. In order to achieve the objectives of the study, the researcher provided an overview of the state of universities in the United Kingdom and then tried to provide in-depth results of the study to identify the instruments and techniques of knowledge management, which began to be used as an administrative tool at the level of those institutions. The study found that many UK institutions focus more on information management than knowledge management and that contributing factors have had an impact on the non-use of knowledge management on a large scale. Based on the above, this study was conducted to investigate the extent of possession of knowledge management requirements among the principals of public secondary schools in Mafraq Governorate.

\subsection{The Problem and Questions of the Study}

Starting from the importance of knowledge management in the administrative processes of planning, organization, supervision and evaluation, the importance acquired by schools in general, and secondary schools in particular; which build and prepare individuals for life and the labor market and university education and in order to keep abreast of the accumulation of knowledge and the spread of means of communication where modern life imposed that there is quality of individuals with innovative ideas and can easily adapt to modern technology, it has been found that this type of person needs a modern school to perform its expected roles in society. Besides, the challenges faced by school administrations and the education departments in general, namely: the rapid technological changes and technical developments, and the accompanying huge flow of information and scientific knowledge, in addition to the implications of globalization and other challenges require changing traditional management methods and adopting modern administrative methods, first and foremost the management of knowledge that proved its importance in the fields of industry, economy and in government and private institutions. Thus, it can prove its usefulness in the fields of education and educational fields.

Therefore, this study is intended to demonstrate the role of knowledge management in secondary schools towards achieving comprehensive change towards the educational process as a whole, since school administrations are represented by their directors in particular to ensure knowledge and processes in school administration so that we move from the traditional role and style of the school to the active role, and the transformation to the so-called cognitive school in accordance with the principles of the knowledge economy in education. The present study will seek to answer the following questions:

1. How well do the principals of the public secondary schools in Mafraq Governorate have the knowledge management requirements?

2. Are there any statistically significant differences at the level of significance $\alpha \leq 0.05$ in the possession of knowledge management requirements among the principals of public secondary schools in Mafraq Governorate due to the variable of academic qualification?

3. Are there any statistically significant differences at the level of significance of $\alpha \leq 0.05$ in the possession of knowledge management requirements among the principals of public secondary schools in Mafraq Governorate due to the variable of gender? 


\subsection{Objectives of the Study}

The present study sought to:

1. To identify the extent the possession of knowledge management requirements among the principals of public secondary schools in Mafraq Governorate.

2. To identify the role of variables (gender, academic qualification) in the integration of knowledge management in secondary schools by the principals of these schools.

\subsection{The Importance of Study}

At start, the importance of the current study is to identify the role of the principal in the application of knowledge management in the educational process and the resulting positive effects reflected on the performance of students and employees as a whole. The importance of this study stems from the fact that knowledge management has become a contemporary administrative concept in our time, which is taking an increasing attention from those interested in educational departments, especially educational institutions because of their role in creating and organizing knowledge and making the required change in deliberate and planned at all organizational levels. Based on the importance of knowledge management in administrative functions in the field of education, such as followup, coordination and supervision and because of the lack of educational studies - according to the researcher - this study was to reveal the extent the possession of knowledge management requirements among the principals of public secondary schools in Mafraq Governorate.

\subsection{Study Terms}

Knowledge Management: Hallaq (2014) defined knowledge management as a set of processes and activities that control knowledge through creation, dissemination and use them by using the skills and experiences of individuals and school personnel that are necessary for administrative activities such as decision making and problem solving.

Knowledge management in this study is defined as systematic processes and efforts that help teachers collect, create, classify and store knowledge, distribute it to teachers, and guide it to implement practices to achieve the desired goal.

The Extent of Possession: It is procedurally defined as the amount or quantity known by the principals of public schools in the governorate of Mafraq about the knowledge management and its mechanisms of application in the school administration and the educational process to achieve their goals set, as it was calculated through a questionnaire prepared for this purpose.

School Principal: This person is officially appointed in the school to be responsible for all aspects of administrative, technical and social work within the school. He is the primary responsible for taking appropriate measures to achieve the objectives of the school in coordination with the higher education departments (Ismail, 1999). It is procedurally defined as the person responsible for managing the educational process, including students and teachers, to achieve specific goals.

Public Secondary Schools: They are procedurally defined as schools that contain numbers of students from different stages and are academic secondary or comprehensive secondary.

\subsection{The Limitation of the Study}

1. Spatial Limitations: Secondary schools in Mafraq Governorate.

2. Time limitations: It is done during the first semester 2018.

3. Human Limitations: All secondary school principals in Mafraq Governorate.

\section{Methodology of the Study}

The study was based on the analytical descriptive approach to identify the extent of the possession of knowledge management requirements among the principals of public secondary schools in Mafraq Governorate.

\subsection{Study Population and Sample}

The study population consists of all scool principals in the Hashimite Kingdom of Jordan for the academic year 2018, which are (120) male and female principals at undergraduate levels and (150) male and female principals at postgraduate levels, i.e. (145) male principals, and (125) female principals, leading them to represent the study sample.

\subsection{Study Instrument}

The researcher developed a questionnaire to achieve the objectives of the study based on previous literature such 
as the study (Hallaq, 2014) and (Al-Qahtani, 2013). The questionnaire was distributed to the study sample's members to collect data and analyze it through the SPSS program. A 5-level Likert scale measure of (always, often, sometimes, rarely, never) was used to measure the response of the study sample members to the questionnaire designed for this purpose. They were classified as follows: (never) (1)(Rarely), (2), (sometimes), (3), (often), (4), (always) (5).

\subsection{Validity and Reliability of the Study Instrument}

The validity of the study instrument was verified by presenting it in its preliminary form to (10) specialized raters from university professors in the fields of educational administration, curriculum, teaching, measurement and evaluation, to determine the appropriateness of the items of the study instrument, the extent of validity of the linguistic formulation, the extent of the relevance of the items, as well as mentioning any proposed amendments and suggesting any items they consider necessary and delete the unnecessary items. After the questionaire is returned, the amendments proposed by the competent university professors in their recommendations were done by raters. These amendments were as follows: rewording of some items, deleting some items due to their lack of relevance to the extent of possession of knowledge management requirements among the principals of public secondary schools in Mafraq Governorate. In the light of the amendments, the questionnaire consisted of (20) item.

To ascertain the reliability of the questionnaire, the internal consistency coefficient of the items was calculated using the Cronbach Alph Equation $\alpha$ and the consistency coefficient of the questionnaire was $(0.85)$, so these values were considered acceptable for the purposes of the study.

\subsection{Study Variables}

First: Independent Variables

-Academic qualification with two levels: BA and GA degrees.

-Gender and has two levels: male (principal) and female (principal).

Second: Dependent Variables

-The extent of possession of knowledge management requirements among the principals of public secondary schools in Mafraq Governorate.

\subsection{Responses Correction}

The extent of possession of knowledge management requirements among the principals of public secondary schools in Mafraq Governorate has been classified into five levels (always, often, sometimes, rarely, never) based on the means of the sample responses per item as follows:

-The length of the category $=$ (the upper limit of substitutes - the lower limit of substitutes $) /$ number of levels

-Length of the category $=(5-1) / 3=1.33$

$1+1.33=2.33$

Thus, the limits of the three levels are as follows:

The arithmetic mean, which is less than 2.33 , is considered a low extent of possession.

The arithmetic mean between 2.34 and 3.66 is considered a low extent of possession

The arithmetic mean, which is more than 3.67 , is considered a high extent of possession.

\subsection{Statistical Processing}

The statistical calculations related to the main questions of the study were used, where the arithmetic means and standard deviations were used. The t-test was used to detect the differences in the academic qualification (Bachelor, Postgraduate) and gender differences (male, female).

\section{Results of the First Question Analysis}

\subsection{It Does State}

To what extent is the possession of knowledge management requirements among the principals of public secondary schools in Mafraq Governorate?

To answer this question, the arithmetic means and standard deviations were used. 
Table 1. Shows the extent of the possession of knowledge management requirements among the principals of public secondary schools in Mafraq Governorate.

\begin{tabular}{|c|c|c|c|c|c|}
\hline No & $\begin{array}{l}\text { Descending } \\
\text { order }\end{array}$ & Item & A.M & S.D & Level \\
\hline 1 & 8 & $\begin{array}{l}\text { Knowledge management helps managers create practical workable } \\
\text { ideas }\end{array}$ & 4.33 & 0.76 & High \\
\hline 2 & 12 & $\begin{array}{l}\text { Knowledge management encourages meetings among employees } \\
\text { to share educational knowledge }\end{array}$ & 4.21 & 0.91 & High \\
\hline 3 & 19 & $\begin{array}{l}\text { Knowledge management supports managers when making their } \\
\text { decisions }\end{array}$ & 4.21 & 0.84 & High \\
\hline 4 & 15 & $\begin{array}{l}\text { Knowledge management provides the right environmental } \\
\text { conditions for doing business }\end{array}$ & 4.20 & 0.91 & High \\
\hline 5 & 14 & $\begin{array}{l}\text { Knowledge management is an administrative process that is } \\
\text { concerned with acquiring, storing and using knowledge }\end{array}$ & 4.20 & 0.89 & High \\
\hline 6 & 20 & $\begin{array}{l}\text { Knowledge management supports managers in improving the } \\
\text { learning environment }\end{array}$ & 4.20 & 1.14 & High \\
\hline 7 & 7 & $\begin{array}{l}\text { Knowledge management contributes to solving the various } \\
\text { problems facing the school }\end{array}$ & 4.17 & 0.90 & High \\
\hline 8 & 1 & $\begin{array}{l}\text { Knowledge management can be used to learn about the school's } \\
\text { performance and its teaching staff }\end{array}$ & 4.16 & 0.84 & High \\
\hline 9 & 2 & $\begin{array}{l}\text { Knowledge management contributes to acquiring new knowledge } \\
\text { about modern school }\end{array}$ & 4.16 & 0.97 & High \\
\hline 10 & 5 & $\begin{array}{l}\text { Knowledge management contributes to the future work plan of the } \\
\text { school }\end{array}$ & 4.16 & 0.94 & High \\
\hline 11 & 9 & $\begin{array}{l}\text { Knowledge management embraces the idea of knowledge } \\
\text { economy-based learning }\end{array}$ & 4.14 & 0.76 & High \\
\hline 12 & 16 & $\begin{array}{l}\text { Knowledge management is a knowledge base for individuals and } \\
\text { organizations }\end{array}$ & 4.14 & 0.95 & High \\
\hline 13 & 3 & $\begin{array}{l}\text { Knowledge management allows teachers to launch their } \\
\text { knowledge and apply it on the ground }\end{array}$ & 4.06 & 0.82 & High \\
\hline 14 & 4 & $\begin{array}{l}\text { The school has a modern library and means of communication that } \\
\text { enable its users to obtain the required knowledge }\end{array}$ & 4.06 & 0.97 & High \\
\hline 15 & 11 & $\begin{array}{l}\text { The school has special recording files to record information and } \\
\text { knowledge }\end{array}$ & 4.04 & 0.84 & High \\
\hline 16 & 10 & $\begin{array}{l}\text { The school has a strategic plan to implement knowledge } \\
\text { management }\end{array}$ & 4.04 & 1.00 & High \\
\hline 17 & 18 & $\begin{array}{l}\text { The school holds training workshops on awareness raising for } \\
\text { knowledge management among staff }\end{array}$ & 4.03 & 0.98 & High \\
\hline 18 & 6 & $\begin{array}{l}\text { Knowledge management works to create an interactive } \\
\text { environment for collecting, documenting, and imparting the } \\
\text { acquired and accumulated experience in school }\end{array}$ & 4.01 & 0.86 & High \\
\hline 19 & 13 & Knowledge management enables participants to make decisions & 4.01 & 0.98 & High \\
\hline 20 & 17 & $\begin{array}{l}\text { Knowledge management helps in identifying different school } \\
\text { needs }\end{array}$ & 4.00 & 0.97 & High \\
\hline Sum & & & 4.13 & 0.90 & High \\
\hline
\end{tabular}

Table (1) shows that the arithmetic means ranged from 4.33 to 4.00 , with a general medium of 4.13 indicating a high extent of possession, and the highest arithmetic mean of the item (Knowledge management helps managers create practical workable ideas) with an arithmetic mean of (4.33) and a standard deviation of (0.76) with a high degree. Then, it is followed by two items of (Knowledge management encourages meetings among employees to share educational knowledge) and (Knowledge management supports managers when making their decisions) with an arithmetic mean of 4.21 and a standard deviation of 0.91 and 0.84 respectively. Then, they are followed by items (Knowledge management provides appropriate environmental conditions for the exercise of work), (Knowledge management provides appropriate environmental conditions for the exercise of work) and (Knowledge Management helps managers to create workable practical ideas) with an arithmetic mean of (4.20) 
and a standard deviation of $(0.91,0.89,1.14)$ respectively.

The penultimate rank was for the item (Knowledge management enables participants to make decisions) with an arithmetic mean of (4.01) and a standard deviation of (.98). The last rank was for the item (Knowledge management helps in identifying different school needs) with an arithmetic mean of 4.00 and a standard deviation of (.97). This is due to the fact that the Ministry of Education based on the idea of the implementation of the strategy of knowledge management in schools and the ministry as a whole is keen to make the educational process more mature and open to the world in which we live and able to adapt to its variants. The new legislation for the selection of school principals emphasizes several criteria that the school principal should enjoy it until the educational and school environment becomes compatible with the requirements of the knowledge economy. The training courses for school principals such as ICDL and INTEL courses and other courses offered by the ministry have made school principals employ all new Knowledge and what serves their schools and students in all their positions. Therefore, the application of knowledge management and the need to have it by the principals will improve the educational process and the working environment for teachers as well as in taking administrative decisions. This result coincided with the study of (Al-Qahtani, 2013) and the study (Al-Lahiani, 2010).

\subsection{Results of the Analysis of the Second Question}

It does state: Are there significant differences at the level $\alpha \leq 0.05$ in the extent of the possession of knowledge management requirements among the principals of public secondary schools in Mafraq Governorate?

To answer this question, the T-test was used. Table 2.3 shows the results of the difference of the extent of the possession of knowledge management requirements among the principals of public secondary schools in Mafraq Governorate according to the difference of the academic qualification (Bachelor, Postgraduate).

Table 2. Shows the arithmetic means and standard deviations of the extent of the possession of knowledge management requirements among the principals of public secondary schools in Mafraq Governorate according to the difference of the academic qualification (Bachelor, Postgraduate).

\begin{tabular}{llll}
\hline Academic Qualification & Number & A.M & S.D \\
\hline Postgraduate & 150 & 3.07 & 115 \\
Bachelor & 120 & 2.85 & 0.92 \\
Sum & 270 & & \\
\hline
\end{tabular}

It is clear from the table that the arithmetic mean of the postgraduate category was 3.07 with a standard deviation of (1.15), while the arithmetic mean was (2.85) was a standard deviation of $(0.92)$ for the bachelor category.

Table 3. shows the results of the T-test to identify differences in the extent of the possession of knowledge management requirements among the principals of public secondary schools in Mafraq Governorate due to the difference of the academic qualification (Bachelor and Postgraduate).

\begin{tabular}{lllllr}
\hline Academic Qualification & Number & A.M & S.D & T-test & Sig \\
\hline Postgraduate & 150 & 3.07 & 1.15 & 2.04 & 0.04 \\
Bachelor & 120 & 2.85 & 092 & & \\
Sum & 270 & 3.275 & & & \\
\hline
\end{tabular}

The results of Table (3) indicate that there is a difference in the possession of knowledge management requirements among the principals of public secondary schools in Mafraq Governorate due to the difference of the academic qualification with (2.04) which is significant at the level of $(\mathrm{a}=0.5)$. So, there is a difference in the extent of possession of principals with a postgraduate qualification that was higher compared to principals who have a bachelor's degree. This can be explained that those who receive certificates of higher education have more knowledge in all aspects of curricula and methods of teaching and management, etc. It is also known that those who complete the postgraduate studies are familiar with everything that is new, especially in the field of education. The principals who complete their academic studies are more flexible and experienced in their field of work. This confirms that experience may not be a solution to some problems in the follow-up of modern and cognitive methods in school administration as an example. Hence, it is possible to say in general that the difference in the academic qualification for school principals is clearly reflected in the application and possession of their knowledge management skills as the so-called academic qualification may make a difference in the decision- 
making process for principals. In the same positions, we find that the application of the management of the situation is not mastered by some principals despite their experience is long in this area. This result was agreed with the study of Abu Al-Khair and Al-Agha (2012) and differed with the study of Al-Lahiani (2010) and Halaq's study (2014).

\subsection{The Results of the Third Question Analysis:}

It does states

Are there statistically significant differences at the level of $\alpha \leq 0.05$ in the possession of knowledge management requirements among the principals of public secondary schools in Mafraq Governorate due to gender variable (male and female?

To answer this question, the T-test of two independent samples was used for the difference in the extent of the possession of knowledge management requirements among the principals of public secondary schools in Mafraq Governorate due to difference of gender (male and female? Table 4 shows.

Table 4. shows results of the T-test to measure the differences between the means of male and female grades in the extent of possession of the knowledge management requirements by the secondary school principals in Mafraq governorate

\begin{tabular}{llllll}
\hline Gender & Number & A.M & S.D & T-test & Sig \\
\hline Males & 145 & 41.31 & 5.67 & $1.01-$ & 0.32 \\
Females & 125 & 48.92 & 5.14 & $0.88-$ & 0.39 \\
\hline
\end{tabular}

Table 4 shows that the differences among the means did not reach the level of statistical significance at the level of $(0.05)$ and less, which amounted to (1.01) at the level (0.32), So, there is no difference in the extent of possession of the knowledge management requirements by the secondary school principals in Mafraq governorate due to the difference of gender (Male and Female) as it is computer. This can be explained by the fact that school principals are similar in the work environment and nature, through which they perform clear and specific tasks and get the same training workshops of different kinds from the responsible authority, namely the Ministry of Education. Therefore, we find that the application of knowledge management in general is not affected by the gender of the official or principal, and a familiar plan of action. There is also a similarity in their understanding of the application of knowledge management in their schools as well. For example, they have the same ideas and views. It is also possible to say that principals in schools work in one field and have one goal and are subject to the same laws and regulations. In other words, they face the same educational reality and the same standards applying in the school administration. Therefore, this result was concluded with studies of (Khalili, 2006) and (Barber, 2014).

The findings of the study can be summarized as follows:

The extent of possession of the knowledge management requirements by the secondary school principals in Mafraq governorate was high.

1. The results showed that there were statistically significant differences at the level of 0.05 and less according to the academic qualification (Postgraduate)

2. The results showed that there were no statistically significant differences at the level of 0.05 .

3. The results showed that there were no statistically significant differences at the level of 0.05 or less due to the difference in gender.

\section{The Researcher Recommends the Following}

1. To increase the training workshops for school principals and employees to make the knowledge management better and benefit from it in the field of education.

2. To benefit from the information and communication revolution in the field of education.

3. To implement the knowledge management strategy as received from the Ministry of Education and train all participants on its terms and contents.

4. To work on linking schools to each other through electronic networking networks because of the importance and exchange of experiences.

\section{References}




\section{References in Arabic}

Agha, N., \& Abu al-Khair, A. (2012). The Reality of the Application of Knowledge Management Processes in AlQuds Open University and the Procedures for its Development. Al-Aqsa University Journal - Human Sciences Series, 16(1), 30-62.

Al Naji, Mohammed Abdullah. (2005). Educational Administration and School, Theories and Practices in the Kingdom of Saudi Arabia.

Al-Ani, Mezher, J., Shawqi, H., \& Haitham (2012). Business Intelligence and Information Technology. (1) Amman: Dar Safa for Publishing and Distribution.

Al-Falawi, H. (2007). Knowledge Management, the Future of Education in the Knowledge Society, Riyadh: The Scholastic House of Education.

Alhayani, M. B., \& Radi, M. (2010). Knowledge Management Introduction to the Development of school administration in the Secondary Stage for Girls from the Point of View of Principals and Teachers in Makkah area (Master Thesis), Faculty of Education, Umm Al Qura University.

Ali, Abdul S., Kandiliji, A., \& Omri, G. (2009). Introduction to Knowledge Management. (Ii) Amman: Dar Al Masirah for Publishing and Distribution.

Alian, R. (2012). Knowledge Management. (1) Amman: Dar Safa for Publishing and Distribution.

Al-Qahtani, M. (1433). The Reality of the Implementation of Knowledge Management in the Schools of the Development Project in the City of Riyadh from the Point of View of Principals and Teachers. (Unpublished master thesis), Imam Muhammad bin Saud Islamic University, Riyadh, Saudi Arabia.

Al-Sabbagh, E. (2002). Knowledge Management and its Role in Laying the Foundations of the Arab Information Society. Arab Journal, 23(2), 37-56.

Amiri, S., \& Al-Ghalbi, T. (2007). Management and Business. (1) Amman: Dar Wael Publishing and Distribution.

Barber, R. A. (2014). The Role of Knowledge Management in Decision Making from the Perspective of Principals and Teachers in Public Secondary Schools in Damascus, Master Thesis, University of Damascus, Syria.

Hijazi, H. (2005). Knowledge Management: A Theoretical Approach. (1) Amman: Al Ahlia for Publishing and Distribution.

Karasna, A. F., \& Khalili, S. (2009). Knowledge Management Components, Analytical Study at the Jordanian Ministry of Education. Jordanian Journal of Business Administration, 5(3), 293-325.

Khalili, S. (2006). Knowledge Management at the Jordanian Ministry of Education. Unpublished Master Thesis, Yarmouk University, Irbid, Jordan.

Kubaisi, S. (2005). Knowledge Management. Cairo: Arab Organization for Administrative Development.

Maani, A. (2009). Trends of Directors in Jordanian Ministries' Centers for Role of Knowledge Management in Job Performance. Jordan Journal of Business Administration, 5(3), 371-411.

Mohamed, I. M. (1999). Problems Facing Mixed Secondary School Principals in Palestine, Unpublished Master Thesis, An-Najah National University, Nablus, Palestine.

Moussa, S. D. (2006). Reasons for the Shift towards the Knowledge Economy in Jordan, its Objectives and Problems from the Point of view of Educational Experts, unpublished PhD thesis, Graduate School of Law, Jordan.

Rafaai, G., \& Yasin, S. (2004). The Role of Knowledge Management in Reducing Credit Risk: An Empirical Study, Paper presented to the Fourth Annual International Scientific Conference (Knowledge Management in the Arab World), AL-Zaytoona University, Amman, 26-28 April 2008.

Razouki, N. (2005). The New Role of the Information Profession in the era of Knowledge Engineering and Management. King Fahd National Library Journal, 10(2), 105-123.

\section{References in English}

Carenfield, D. (2011). Knowledge management and higher education: a UK case study using grounded theory. University of Southampton, School of, Management Doctoral, Thesis, p390.

Chen, L. C., Chu, P. Y., \& Wei, W. L. (2007). A study on the effect of using knowledge management system in design education International of association societies of design researches, Hong Kong Poly Technic University. 
Denning, S. (2003). What is knowledge management? Retrieved December 5, 2009, from http://www.stevedenning.com

Keeley, E. (2004). Institutional research as the catalyst for the extent and Effectiveness of knowledge management practices in improving planning and decisions making in higher education organizations. U.S.A. Retrieved from http://proquest.umi.com/pqdweb

Malhorta Y. (1999). Wite Knowledge Management for Organization Rastogi, 2000 PN Rastogi Human system Management 2000 IoS Press.

\section{Copyrights}

Copyright for this article is retained by the author(s), with first publication rights granted to the journal.

This is an open-access article distributed under the terms and conditions of the Creative Commons Attribution license (http://creativecommons.org/licenses/by/4.0/). 